\title{
Proteasome Inhibitors as a Possible Therapy for SARS-CoV-2
}

\author{
Lucia Longhitano ${ }^{1,+}$, Daniele Tibullo ${ }^{1,+}+\mathbb{D}$, Cesarina Giallongo ${ }^{2, *}$, Giacomo Lazzarino ${ }^{3}$, \\ Nicola Tartaglia ${ }^{4}(0)$, Sara Galimberti ${ }^{5}$, Giovanni Li Volti ${ }^{1, * \mathbb{C}}$, Giuseppe Alberto Palumbo ${ }^{2, \neq}$ \\ and Arcangelo Liso $4, \mp(1)$
}

1 Section of Biochemistry, Department of Biomedical and Biotechnological Sciences, University of Catania, 95123 Catania, Italy; lucia.longhitano@phd.unict.it (L.L.); d.tibullo@unict.it (D.T.)

2 Section of Haematology, Department of Scienze Mediche Chirurgiche e Tecnologie Avanzate "G.F. Ingrassia", University of Catania, 95123 Catania, Italy; giuseppealberto.palumbo@gmail.com

3 UniCamillus-Saint Camillus International University of Health Sciences, Via di Sant'Alessandro 8, 00131 Rome, Italy; giacomo.lazzarino@unicamillus.org

4 Department of Medical and Surgical Sciences, University of Foggia, 71100 Foggia, Italy; nicola.tartaglia@unifg.it (N.T.); arcangelo.liso@unifg.it (A.L.)

5 Section of Hematology, Department of Clinical and Experimental Medicine, University of Pisa, 56121 Pisa, Italy; sara.galimberti@med.unipi.it

* Correspondence: cesarina.giallongo@unict.it (C.G.); livolti@unict.it (G.L.V.)

+ These authors equally contributed to this work as co-first.

$\ddagger \quad$ These authors equally contributed to this work as co-last.

Received: 29 April 2020; Accepted: 18 May 2020; Published: 20 May 2020

\begin{abstract}
The COVID-19 global pandemic is caused by SARS-CoV-2, and represents an urgent medical and social issue. Unfortunately, there is still not a single proven effective drug available, and therefore, current therapeutic guidelines recommend supportive care including oxygen administration and treatment with antibiotics. Recently, patients have been also treated with off-label therapies which comprise antiretrovirals, anti-inflammatory compounds, antiparasitic agents and plasma from convalescent patients, all with controversial results. The ubiquitin-proteasome system (UPS) is important for the maintenance of cellular homeostasis, and plays a pivotal role in viral replication processes. In this review, we discuss several aspects of the UPS and the effects of its inhibition with particular regard to the life cycle of the coronaviruses (CoVs). In fact, proteasome inhibition by various chemical compounds, such as MG132, epoxomycin and bortezomib, may reduce the virus entry into the eucariotic cell, the synthesis of RNA, and the subsequent protein expression necessary for CoVs. Importantly, since UPS inhibitors reduce the cytokine storm associated with various inflammatory conditions, it is reasonable to assume that they might be repurposed for SARS-CoV-2, thus providing an additional tool to counteract both virus replication as well as its most deleterious consequences triggered by abnormal immunological response.
\end{abstract}

Keywords: SARS-CoV-2; proteasome inhibitors; endoplasmic stress; UPR response

\section{Introduction}

Since December 2019, infection with the severe acute respiratory coronavirus 2 (SARS-CoV-2) has become a worldwide emergency (pandemic) for which a rapid action is required [1,2]. In particular, COVID-19 (the illness caused by SARS-CoV-2) is overwhelming even well-organized national health care systems on a global scale [3,4]. Unfortunately, the symptoms of SARS-CoV-2 infection can vary in an unpredictable manner; there are asymptomatic cases as well as patients suffering from pneumonia, acute respiratory distress syndrome and multisystem organ failure $[5,6]$. Older patients and patients 
with preexisting respiratory or cardiovascular conditions appear to be at the greatest risk for severe complications and death [6,7]. In the absence of a proven effective therapy, current management consists of supportive care, including ventilation and treatment with antibiotics [8,9]. Moreover, patients are often treated with off-label therapies, including antiretrovirals, anti-inflammatory compounds, antiparasitic agents, and in a few cases, plasma from recently cured patients [10-13]. Antimalarial agents like chloroquine are used to block the virus entry, while new drugs like tocilizumab, anakinra or ruxolitinib [14], directed against a specific key element of the inflammatory response, are used to switch off the cytokine storm [15], as are antiviral drugs [16]. Nevertheless, in the absence of long-term and controlled clinical trials, there is no consensus on a "state of the art" therapeutic approach. Indeed, the use of drugs to stall the virus attack, followed by blocking viral replication and, in patients with signs of higher cytokine/chemokine release, the "pre-emptive" use of anti-IL6 or anti-IL1 blocking antibodies could be proposed $[17,18]$. Here, we review the potential role of proteasome inhibitors, based on previous studies showing that the ubiquitin-proteasome system is involved in the replication of a broad range of viruses.

\section{SARS-CoV-2}

Coronaviruses belong to the Coronaviridae family in the order of Nidovales. They are approximately $65-125 \mathrm{~nm}$ in diameter and are single-stranded RNA viruses (+ ssRNA). The Coronavirus family includes four subgroups: $\alpha-, \beta-, \gamma$ - and $\delta$-; among them, $\alpha$ - and $\beta-\mathrm{CoV}$ are capable of infecting mammals (Figure 1 ), while $\gamma$ - and $\delta$-CoVs mainly infect birds. Two well-known $\beta$-CoVs are SARS-CoV, responsible for the 2003 epidemic started in China (that caused 8000 infections and 800 deaths i.e., a 10\% mortality rate), and MERS-CoV, which was responsible for the 2012 epidemic that began in Saudi Arabia (causing 2400 infections and 800 deaths i.e., a 35\% mortality rate) [19,20]. Genomic analysis revealed that the new Coronavirus, SARS-CoV-2 is a $\beta$-Coronavirus. The SARS-Cov- 2 viral genome is complex and resembles that of other coronaviruses. In particular, $75 \%$ of the genome is related to viral replicase genes from two open reading frames (ORFs), i.e., ORF1a and ORF1b, encoding for two polyproteins, pp1a (486 kDa) and pp1ab (790 kDa).The 1 ribo-some frame-shift occurs immediately upstream of the ORF1a stop codon, which allows the continuous translation of ORF1b to occur, producing a large polypeptide (pp1ab, 740-810 kDa) which is divided into $15 \mathrm{nsps}$. Proteolytic cleavage is mediated by the viral proteases nsp3 and nsp5 which, respectively, host a papain-like placenta domain and a 3C-like protease domain. Moreover, at short motifs called transcription-regulatory sequences (TRSs) that are located immediately adjacent to ORFs, the protease domain contains a conserved 6-7 nt core sequence (CS) surrounded by variable sequences [21]. Coronaviruses exhibit a round morphology and are constituted of several components, such as glycoprotein S (Spike), organized in trimers on the external part of the virion resembling a crown, from which they take their name; this protein determines the virus specificity for epithelial cells. In fact, it has been suggested that SARS-CoV-2 enters the host cell through the angiotensin-2 conversion receptor, ACE2, and CD26 (like SARS-CoV), expressed at both pulmonary and gastrointestinal levels (that's why there are also symptoms at these compartments) [22]. Protein $M$ crosses the envelope and interacts within the virion with the RNA protein complex. HE protein, the hemagglutinin esterase, is important during the virus release phase inside the host cell. The Protein E helps protein S attach to the target cells membranes. Finally, RNA gives rise to 7 viral proteins and is associated with the $\mathrm{N}$ protein, which increases its stability (Figure 1).

According to the evolutionary tree, SARS-CoV-2 is located close to the SARS-coronavirus group [23,24]. Recent studies have indicated significant variations in SARS-CoV and SARS-CoV-2, such as the absence of protein $8 \mathrm{a}$ and the fluctuation in the number of amino acids in protein $8 \mathrm{~b}$ and $3 \mathrm{c}$ in SARS-CoV-2 [6]. Spike glycoprotein from the Wuhan coronavirus was modified by homologous recombination. Particularly, the spike glycoprotein of SARS-CoV-2 is a mixture of SARS-CoV bat and an unknown Beta-CoV [24]. The SARS-CoV-2 genome is $29.9 \mathrm{~kb}$ [25], while those of SARS-CoV and MERS-CoV are 27.9 and $30.1 \mathrm{~kb}$, respectively [26]. The glycoprotein S comprises two subunits, S1 and S2 [27]. S1 determines the viral host flow rate and cell tropism with the key function 
domain-receptor-binding domain (RBD), while S2 mediates cell-cell membrane fusion through heptad repeat 1 (HR1) and 2 (HR2) [28,29]. Starting from the viral RNA, the synthesis of two 1a/1ab polyproteins (pp1a pp1ab) takes place in the host [30]. Transcription works through the replication-transcription complex (RTC), organized in double membrane vesicles, which continuously replicates and synthesizes subgenomic RNAs [31] and, in turn, encodes accessory and structural proteins. The endoplasmic reticulum (ER) and Golgi [32], genomic RNA, N protein and envelope glycoproteins come together to form viral bud particles. The vesicles containing virions then merge with the plasma membrane and release the virus. Transcription termination occurs in regulatory transcription sequences, located between open reading frames (ORFs), i.e., models for the production of subgenomic mRNA. In CoV, there are about 6 ORFs, and a frame-shift between ORF1a and ORF1b drives the production of pp1a and pp1ab, while the other ORFs encode for structural proteins S, E, M, N [30] and accessory proteins that interfere with the host's innate immune response [2]. As mentioned, it has been suggested that SARS-CoV-2, like SARS-CoV, uses the ACE2 receptor to enter the host cell [33], but a N501T mutation in protein $S$ of SARS-CoV-2 may result in a better binding affinity for ACE2 [34]. Systematic detection of $\beta-\mathrm{CoV}$ receptors has shown that human cells expressing ACE2 have improved SARS-CoV-2 access [35].

A



B

\begin{tabular}{|c|c|c|}
\hline Human Coronavirus 229E & HCoV-229E & Alpha - CoV : Duvinacovirus \\
\hline Human Coronavirus OC43 & HCoV- 0 C43 & Beta - CoV : Embecovirus \\
\hline Human Coronavirus NL63 & HCoV- NL63 & Alpha - CoV : Setracovirus \\
\hline $\begin{array}{c}\text { Human Coronavirus HKU1 } \\
\text { Severe Acute Respiratory Syndrome } \\
\text { Coronavirus }\end{array}$ & HCoV- HKU1 & Beta - CoV : Embecovirus \\
\hline $\begin{array}{c}\text { Middle East Respiratory Syndrome Coronavirus }- \text { CoV } \\
\text { Severe Acute Respiratory Syndrome } \\
\text { Coronavirus - } 2\end{array}$ & MERS - CoV & Beta - CoV : Sarbecovirus \\
\hline
\end{tabular}

Figure 1. (A) Structure of the coronavirus. (B) The 7 Coronaviruses known to infect humans.

Angeletti et al. compared the gene sequence of SARSars-Cov-2 with that of SARSars-CoV. They analyzed the transmembrane helical segments in coded ORF1ab 2 (nsp2) and nsp3 and found that position 723 has a residue of serine instead of glycine, while position 1010 is occupied by proline instead of isoleucine [36]. The issue of viral mutations is the key to explaining potential relapses of 
the disease. At the protein level, no amino acid substitutions occur in rotavirus nonstructural protein families (NSPs), NSP7, NSP13, envelope, matrix or accessory proteins $\mathrm{p} 6$ and $8 \mathrm{~b}$, with the exception of NSP2, NSP3, spike protein, subdomain below, or RBD. Other recent research [37] has suggested that the mutation in NSP2 and NSP3 has a role in the infectious ability and differentiation mechanism of SARS-CoV-2.

\section{Currently-Available Therapies}

To date, there is no vaccine available, nor a specific antiviral therapy for SARS-CoV-2. The current therapeutic strategies used to cope with this pandemic are mainly based on symptomatic and respiratory support. On 28 January 2020, the WHO published a document summarizing its guidelines and scientific evidence derived from the treatment of previous HCoV epidemics [30]. Furthermore, the scientific world works constantly and is looking for an effective therapy, mainly based on strategies previously used against SARS-CoV and MERS - CoV. Interferons nebulization and various antivirals were initially used, including Nafamostat, Nnitazoxanide, Rribavirin, Penciclovir, Ffavipiravine, Rritonavir, Baricitinib, Lopinavir, Oseltamir and Arbidol. However, Remdesivir has been shown to be most effective in reducing viral load [38] (GS5734). As an RNA polymerase inhibitor, it has been shown, alone or in combination with chloroquine or interferon- $\beta$, to effectively block the replication of SARS-CoV-2 [39-41]. Based on experience in the fight against SARS-CoV and MERS-CoV, antiviral drugs and systemic treatment with corticosteroids commonly used previously in clinical practice, including neuraminidase inhibitors (Oseltamivir, Peramivir, Zanamivir, etc.), Ganciclovir, Aciclovir and Rribavirin, as well as methylprednisolone [42,43] for the influenza virus, are not valid for COVID-19 and are not recommended. Another effective drug is chloroquine (500 mg every $12 \mathrm{~h}$ ) and hydroxychloroquine (200 mg every $12 \mathrm{~h}$ ), drugs used for many years in the treatment of malaria, and today also in the treatment of rheumatoid arthritis. Several possible mechanisms have been studied. Chloroquine can inhibit the pH-dependent phases of the replication of different viruses [44], with a powerful effect on the infection and spread of SARS-CoV [45]. Furthermore, chloroquine has immuno-modulatory effects, suppressing the production/release of TNF- $\alpha$ and IL-6. Several studies have found that chloroquine interferes with the glycosylation of SARS-CoV cell receptors [45], and has worked in both the entry and postentry stages of COVID-19 infection in Vero E6 cells [41]. In Italy, a large survey conducted by the National Cancer Institute and the Pascale Foundation of Naples focused on the use of tolicizumab. It is a humanized IgG1 monoclonal antibody, directed against the IL-6 receptor and commonly used in the treatment of rheumatoid arthritis. Passive immunization has been successfully used for the treatment of infectious diseases, and 80 SARS patients were treated with convalescent plasma during the last major outbreak, while the same treatment did not occur for MERS. Since many patients have recovered despite the high number of deaths, this could also be a strategy for SARS-CoV-2.

\section{Inhibition of the Ubiquitin-Proteasome System}

The ubiquitin-proteasome system (UPS) is important for the maintenance of cellular homeostasis and also in viral replication processes. The UPS system is a complex process that leads to the degradation of ubiquitinated target proteins through the cutting action of the proteosome. Proteosome inhibitors are therefore molecules that are capable of inhibiting proteoasome activity, inducing the inhibition of the UPS response. We, in this review, focus our attention on the inhibition of proteasome activity by drugs already routinely used in many tumor pathologies. Some studies have focused on the role played by the ubiquitin-proteasome system and its inhibition in the process of entry and replication of the coronavirus [46]. Moreover, in the destabilization of antiviral proteins, viruses retain proviral or viral proteins by manipulating the ubiquitination processes through the expression of their own deubiquitination proteins (DUBs) [47], which have also been described for SARS-CoV [48,49]. On the other hand, the replication of numerous viruses also depends heavily on the activity of a functional UPS. Several studies have shown that virus infection leads 
to the accumulation of protein-ubiquitin conjugates, suggesting an important role of the increased ubiquitination process in ubiquitin-proteasome-mediated viral replication or protein degradation. Furthermore, the accumulation of proteins explained by the inhibition of proteasome activity causes a blockage of protein synthesis, endoplasmatic reticulum stress and cell death, leading to the inhibition of viral replication [50,51].

The best-known proteasome inhibitor is Bortezomib (Valcade) [50], which was approved in 2008 as a first-line drug in the treatment of multiple myeloma. Other inhibitors are MG132, Lactacistin, Carfilzomib, Ixazomib and others which are able to target the 20S and 19S subunits (Figure 2) [49,52]. Interestingly, Computational Drug Repurposing Studies showed that Carfilzomib is a good candidate for the treatment of COVID-19 [53].

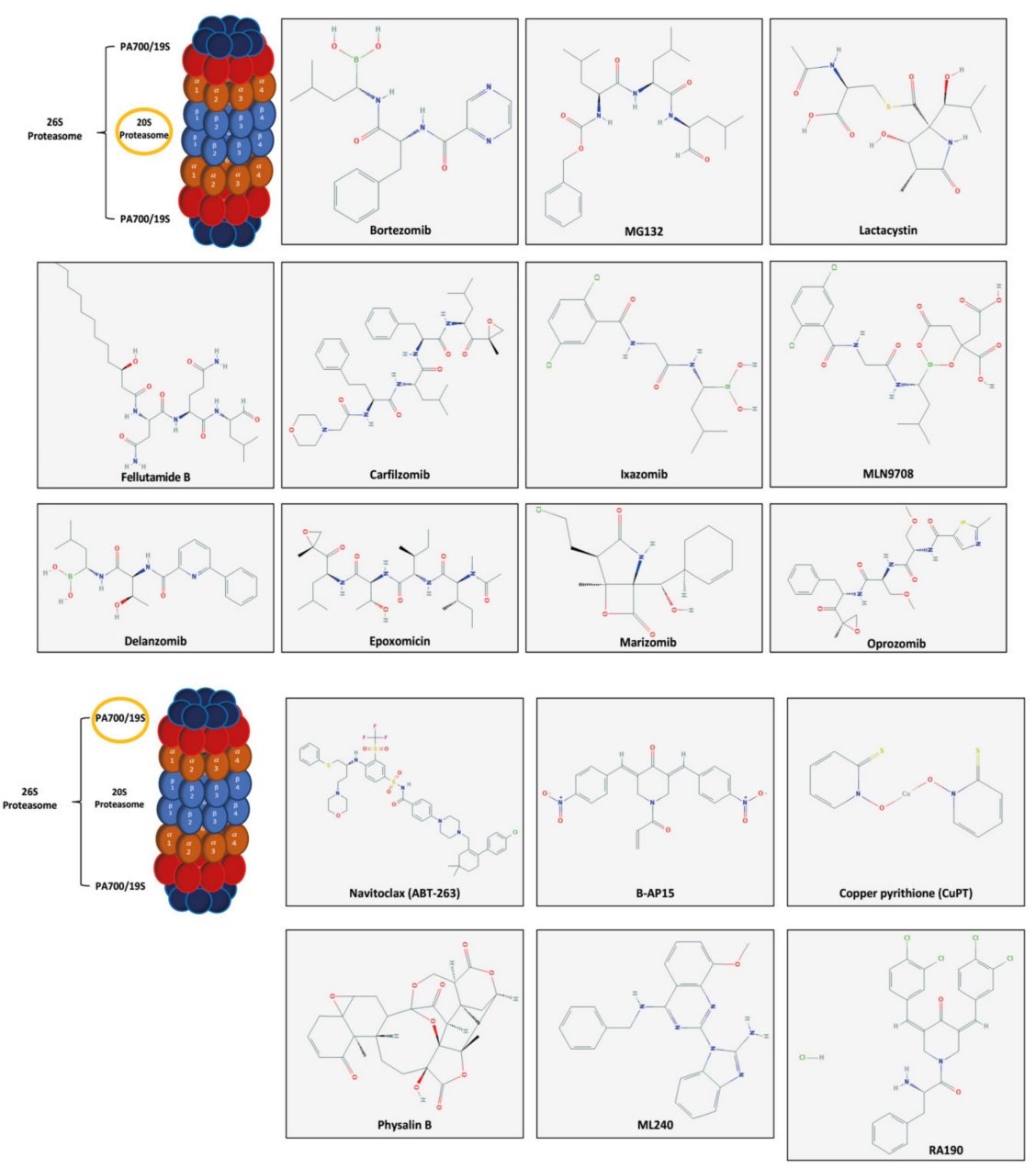

Figure 2. Chemical structures of several proteasome inhibitors. In yellow circle the subunit target of the drugs. Pubchem.

As mentioned, one of the effects of coronavirus infection is the pro-inflammatory cytokine storm that occurs mainly in patients with severe respiratory conditions. The inhibition of the ubiquitin-proteasome system has proven effective in reducing the inflammatory response. In particular, a study by Moutzouris et al. [54] evaluated the anti-inflammatory effect of UPS inhibition in an airway smooth muscle (ASM) cell line. Specifically, this study demonstrated that cells treated with the MG132 inhibitor showed a reduction in IL-6 levels and other cytokines like sICAM-1, IP-10, MCP-1, MIF, RANTES, but also in the upregulation of MKP-1, a negative regulator of the serine/threonine protein kinases MAPK, which, once activated, plays a crucial role in a wide variety of cellular functions, ranging from proliferation to migration and synthesis of fibrotic and inflammatory proteins, including cytokines. Therefore, MAPK inhibition has emerged as an attractive strategy for reversing inflammation and 
remodeling in a wide variety of chronic inflammatory conditions [54]. Therefore, overall, the Moutzouris study suggests that UPS inhibition is an effective means of increasing the levels of the MAPK deactivator, MKP-1, and that, therefore, it could represent a possible therapeutic target in inflammatory conditions. Despite this, it is known that the ubiquitin-proteasome system is also important for the endocytosis and maturation of some viruses. Already in 2005, after the first SARS-CoV epidemic, in a study by Yi Yu et al. concerning the murine hepatitis virus (MHV-JHM strain, belonging to the Coronaviridae family), it was shown that the ubiquitin-proteasome system is involved in the release of the virus from the endosome to the cytosol during the virus entry phase. Proteasome inhibitors (lactacistin and MG132) inhibit MHV replication, demonstrating that the ubiquitin-proteasome system is involved in the early stages of virus replication, as the inhibitory effect was observed mainly from 0 to $6 \mathrm{~h}$ after treatment. It was stressed, however, that proteasome inhibition does not block the internalization of the virus. Furthermore, in the presence of MG132, most viruses remained in the vesicles, both endosomes and lysosomes, and therefore, are protected by RNase digestion [55]. Therefore, although MHV can be internalized in the cell in the absence of a functional ubiquitin-proteasome system, viruses within endosomes or lysosomes cannot be released into the cytosol [55]. Indeed, SARS-CoV, which binds to its functional receptor ACE2 [56], is internalized by endocytosis, and viral RNA is released from the endosome [56-59]. In the cytosol, the SARS-CoV genome is translated into two large polyproteins which are processed autocatalytically to produce nonstructural proteins (nsps), including all the nsps of the replicase viral complex [60-62]. Protected by double membrane vesicles (DMV), most likely originating from endoplasmic reticulum (ER) membranes [63], the genome is replicated and, by generating specific sets of subgenomic mRNA, structural and specific accessory SARS-CoV proteins are produced $[61,62]$. After assembly and budding processes in the endoplasmic reticulum of the Golgi intermediate compartment (ERGIC) [64,65], mature virions are released by exocytosis. Proteasome inhibition by various chemical compounds (e.g., MG132, Eepoxomycin and VelcadeBortezomib) seems not only to compromise the entry, but also the synthesis of RNA and the subsequent protein expression of different CoVs (e.g., Hepatitis Virus of mouse [MHV], feline infectious peritonitis virus, and severe acute respiratory syndrome CoV) [66]. A 2010 study by Raaben et al. showed that in cells treated with UPS chemical inhibitors, the synthesis of the viral CoV RNA and the subsequent protein expression were strongly reduced in all experimental conditions, while the entry of the virus was influenced only by chemical proteasome inhibitors [66]. In particular, the authors attempted to determine whether the inhibition of virus infection caused by MG132 was specific to this proteasome inhibitor or whether it was also observed when other proteasome inhibitors were used. Although MG132 has been shown to also inhibit proteases other than proteasome (i.e., cathepsin A and tripeptidyl peptidase II) [67], Eepoxomomine, Llactacystine and Velcade Bortezomib affect the proteasome more specifically [68-70]. Finally, a 2012 study showed conflicting data with previous work. Schneider et al. showed that the proteasomal inhibitor MG132 strongly inhibits the replication of SARS-CoV by interfering with the early stages of the viral life cycle, but other inhibitors (e.g., Lactacistin and Bbortezomib) only marginally affected viral replication, suggesting that the effect of MG132 is independent of proteasome inhibition, since MG132 also inhibits m-calpain. Interestingly, these authors observed that by using a calpain inhibitor (MDL28170), virus replication was inhibited, suggesting that MG132 does not inhibit SARS-CoV replication by ER stress induction, unexplained protein response or autophagy [47]. Since few studies to date have demonstrated the effects on coronavirus replication, we hypothesize that proteasomal inhibitors may negatively modulate virus replication, primarily acting on blocking protein synthesis due to an increase in stress on the plasma reticulum, and therefore, on the activation of the UPS. In the few papers published, bortezomib did not show great efficacy, but we have new inhibitors, some of which have the ability to bind the proteasome in an irreversible way, such as Ccarfilzomib. Interestingly, Wang et al. performed a molecular dynamics simulation followed by binding free energy calculations, demonstrating that Carfilzomib presented the best binding free energy, and therefore supporting the possible use of this proteasome inhibitor against COVID-19 [53]. 


\section{Conclusions}

In the absence of definitive protocols, effective antiviral care and a vaccine against SARS-CoV-2, the scientific community should explore possible therapeutic strategies, relying mainly on those used in previous epidemics. In this review, we summarized the current knowledge regarding the use of drugs, and in particular of ubiquitin-proteasome system inhibitors, which were proven to be powerful tools in reducing the cytokine storm and in inhibiting virus replication for other coronaviruses (Figure 3). Several molecules appear to be promising candidates; in particular, MG132, epoxomycin, bortezomib and carfilzomib have the potential to affect both viral replication as well as pneumonia and acute respiratory distress syndrome. Further studies are now warranted in order to establish the clinical efficacy of these compounds and to compare the clinical outcomes of patients.

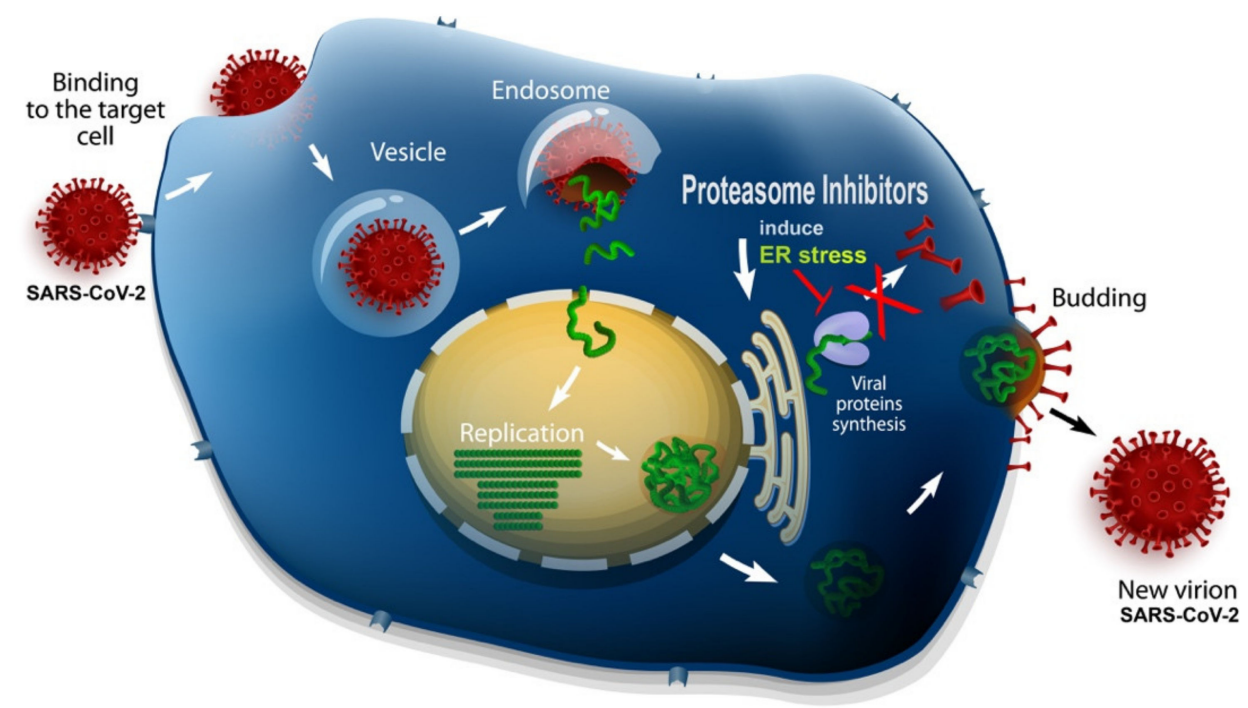

Figure 3. A schematic representation of the possible mechanism of proteasome inhibitors in virus replication.

Author Contributions: Conceptualization, D.T., L.L., A.L., G.L., N.T., C.G., S.G. and G.L.V.; validation, N.T., G.A.P., D.T., L.L.; writing—original draft preparation, D.T., C.G., G.A.P., G.L.V., A.L., N.T.; supervision, A.L., S.G., G.A.P. and G.L.V.; writing-review and editing, S.G., D.T., A.L., G.L. All authors have read and agreed to the published version of the manuscript.

Funding: This research received no external funding.

Conflicts of Interest: The authors declare no conflict of interest.

\section{References}

1. Wang, C.; Horby, P.W.; Hayden, F.G.; Gao, G.F. A novel coronavirus outbreak of global health concern. Lancet 2020, 395, 470-473. [CrossRef]

2. Guo, Y.R.; Cao, Q.D.; Hong, Z.S.; Tan, Y.Y.; Chen, S.D.; Jin, H.J.; Tan, K.S.; Wang, D.Y.; Yan, Y. The origin, transmission and clinical therapies on coronavirus disease 2019 (COVID-19) outbreak-An update on the status. Mil. Med. Res. 2020, 7, 10-11. [CrossRef] [PubMed]

3. Riou, J.; Althaus, C.L. Pattern of early human-to-human transmission of Wuhan 2019 novel coronavirus (2019-nCoV), December 2019 to January 2020. Eurosurveillance 2020, 25, 2000058. [CrossRef] [PubMed]

4. Liu, Y.; Gayle, A.A.; Wilder-Smith, A.; Rocklöv, J. The reproductive number of COVID-19 is higher compared to SARS coronavirus. J. Travel Med. 2020, 27. [CrossRef] [PubMed]

5. Chan, J.F.W.; Yuan, S.; Kok, K.H.; To, K.K.W.; Chu, H.; Yang, J.; Xing, F.; Liu, J.; Yip, C.C.Y.; Poon, R.W.S.; et al. A familial cluster of pneumonia associated with the 2019 novel coronavirus indicating person-to-person transmission: A study of a family cluster. Lancet 2020. [CrossRef] 
6. Wu, A.; Peng, Y.; Huang, B.; Ding, X.; Wang, X.; Niu, P.; Meng, J.; Zhu, Z.; Zhang, Z.; Wang, J.; et al. Genome Composition and Divergence of the Novel Coronavirus (2019-nCoV) Originating in China. Cell Host Microbe 2020. [CrossRef]

7. Lu, R.; Zhao, X.; Li, J.; Niu, P.; Yang, B.; Wu, H.; Wang, W.; Song, H.; Huang, B.; Zhu, N.; et al. Genomic characterisation and epidemiology of 2019 novel coronavirus: Implications for virus origins and receptor binding. Lancet 2020. [CrossRef]

8. Shereen, M.A.; Khan, S.; Kazmi, A.; Bashir, N.; Siddique, R. COVID-19 infection: Origin, transmission, and characteristics of human coronaviruses. J. Adv. Res. 2020, 24, 91-98. [CrossRef]

9. Phan, L.T.; Nguyen, T.V.; Luong, Q.C.; Nguyen, T.V.; Nguyen, H.T.; Le, H.Q.; Nguyen, T.T.; Cao, T.M.; Pham, Q.D. Importation and human-to-human transmission of a novel coronavirus in Vietnam. N. Engl. J. Med. 2020, 382, 872-874. [CrossRef]

10. Parry, J. China coronavirus: Cases surge as official admits human to human transmission. BMJ 2020. [CrossRef]

11. Huang, C.; Wang, Y.; Li, X.; Ren, L.; Zhao, J.; Hu, Y.; Zhang, L.; Fan, G.; Xu, J.; Gu, X.; et al. Clinical features of patients infected with 2019 novel coronavirus in Wuhan, China. Lancet 2020. [CrossRef]

12. Martínez-Sánchez, G. Potential use of ozone in SARS-CoV-2/COVID-19. Available online: $\quad$ https://www.google.com.hk/url?sa=t\&rct=j\&q=\&esrc=s\&source=web\&cd=1\&ved= 2ahUKEwjlkamFncLpAhWwGqYKHZ1YDwsQFjAAegQIAhAB\&url=https\%3A\%2F\%2Faepromo. org\%2Fcoronavirus\%2Fpdfs_doc_ISCO3\%2FCovid19_en.pdf\&usg=AOvVaw2wQjtRjoH-KWfgGcsosl22 (accessed on 19 May 2020).

13. Mauro, R.D.; Cantarella, G.; Bernardini, R.; Rosa, M.D.; Barbagallo, I.; Distefano, A.; Longhitano, L.; Vicario, N.; Nicolosi, D.; Lazzarino, G.; et al. The biochemical and pharmacological properties of ozone: The smell of protection in acute and chronic diseases. Int. J. Mol. Sci. 2019, 20, 634. [CrossRef] [PubMed]

14. Elli, E.M.; Baratè, C.; Mendicino, F.; Palandri, F.; Palumbo, G.A. Mechanisms Underlying the Anti-inflammatory and Immunosuppressive Activity of Ruxolitinib. Front. Oncol. 2019, 9, 1186. [CrossRef] [PubMed]

15. Zhang, W.; Zhao, Y.; Zhang, F.; Wang, Q.; Li, T.; Liu, Z.; Wang, J.; Qin, Y.; Zhang, X.; Yan, X.; et al. The use of anti-inflammatory drugs in the treatment of people with severe coronavirus disease 2019 (COVID-19): The experience of clinical immunologists from China. Clin. Immunol. 2020, 214, 108393. [CrossRef] [PubMed]

16. Rosa, S.G.V.; Santos, W.C. Clinical trials on drug repositioning for COVID-19 treatment. Revista Panamericana de Salud Pública 2020. [CrossRef]

17. Conti, P.; Ronconi, G.; Caraffa, A.; Gallenga, C.E.; Ross, R.; Frydas, I.; Kritas, S.K. Induction of pro-inflammatory cytokines (IL-1 and IL-6) and lung inflammation by COVID-19: Anti-inflammatory strategies. J. Biol. Regul. Homeost. Agents 2020. [CrossRef]

18. Galimberti, S.; Baldini, C.; Barate, C.; Ricci, F.; Balducci, S.; Grassi, S.; Ferro, F.; Buda, G.; Benedetti, E.; Fazzi, R.; et al. The CoV-2 outbreak: How hematologists could help to fight Covid-19. Pharmacol. Res. 2020, 157, 104866. [CrossRef]

19. WHO. Summary of Probable SARS Cases with Onset of Illness from 1 November 2002 to 31 July 2003. 2004. Available online: https://www.who.int/csr/sars/country/table2004_04_21/en/ (accessed on 19 May 2020).

20. Memish, Z.A.; Perlman, S.; Van Kerkhove, M.D.; Zumla, A. Middle East respiratory syndrome. Lancet 2020, 395, 1063-1077. [CrossRef]

21. Kim, D.; Lee, J.Y.; Yang, J.S.; Kim, J.W.; Kim, V.N.; Chang, H. The Architecture of SARS-CoV-2 Transcriptome. Cell 2020. [CrossRef]

22. Yan, R.; Zhang, Y.; Li, Y.; Xia, L.; Guo, Y.; Zhou, Q. Structural basis for the recognition of SARS-CoV-2 by full-length human ACE2. Science 2020. [CrossRef]

23. Hui, D.S.; Azhar, E.I.; Madani, T.A.; Ntoumi, F.; Kock, R.; Dar, O.; Ippolito, G.; Mchugh, T.D.; Memish, Z.A.; Drosten, C.; et al. The continuing 2019-nCoV epidemic threat of novel coronaviruses to global health - The latest 2019 novel coronavirus outbreak in Wuhan, China. Int. J. Infect. Dis. 2020, 91, 264-266. [CrossRef] [PubMed]

24. Li, B.; Si, H.-R.; Zhu, Y.; Yang, X.-L.; Anderson, D.E.; Shi, Z.-L.; Wang, L.-F.; Zhou, P. Discovery of Bat Coronaviruses through Surveillance and Probe Capture-Based Next-Generation Sequencing. mSphere 2020. [CrossRef] [PubMed] 
25. Wu, F.; Zhao, S.; Yu, B.; Chen, Y.M.; Wang, W.; Song, Z.G.; Hu, Y.; Tao, Z.W.; Tian, J.H.; Pei, Y.Y.; et al. A new coronavirus associated with human respiratory disease in China. Nature 2020. [CrossRef] [PubMed]

26. De Wit, E.; Van Doremalen, N.; Falzarano, D.; Munster, V.J. SARS and MERS: Recent insights into emerging coronaviruses. Nat. Rev. Microbiol. 2016, 14, 523-534. [CrossRef]

27. Zhang, N.; Jiang, S.; Du, L. Current advancements and potential strategies in the development of MERS-CoV vaccines. Expert Rev. Vaccines 2014, 13, 761-774. [CrossRef]

28. Xia, S.; Zhu, Y.; Liu, M.; Lan, Q.; Xu, W.; Wu, Y.; Ying, T.; Liu, S.; Shi, Z.; Jiang, S.; et al. Fusion mechanism of 2019-nCoV and fusion inhibitors targeting HR1 domain in spike protein. Cell. Mol. Immunol. 2020, 1-3. [CrossRef]

29. Yu, F.; Du, L.; Ojcius, D.M.; Pan, C.; Jiang, S. Measures for diagnosing and treating infections by a novel coronavirus responsible for a pneumonia outbreak originating in Wuhan, China. Microbes Infect. 2020. [CrossRef]

30. Cascella, M.; Rajnik, M.; Cuomo, A.; Dulebohn, S.C.; Di Napoli, R. Features, Evaluation and Treatment Coronavirus (COVID-19); StatPearls: Bethesda, MD, USA, 2020.

31. Hussain, S.; Pan, J.; Chen, Y.; Yang, Y.; Xu, J.; Peng, Y.; Wu, Y.; Li, Z.; Zhu, Y.; Tien, P.; et al. Identification of Novel Subgenomic RNAs and Noncanonical Transcription Initiation Signals of Severe Acute Respiratory Syndrome Coronavirus. J. Virol. 2005. [CrossRef]

32. Perrier, A.; Bonnin, A.; Desmarets, L.; Danneels, A.; Goffard, A.; Rouillé, Y.; Dubuisson, J.; Belouzard, S. The C-terminal domain of the MERS coronavirusMprotein contains a trans-Golgi network localization signal. J. Biol. Chem. 2019. [CrossRef]

33. Xu, X.; Chen, P.; Wang, J.; Feng, J.; Zhou, H.; Li, X.; Zhong, W.; Hao, P. Evolution of the novel coronavirus from the ongoing Wuhan outbreak and modeling of its spike protein for risk of human transmission. Sci. China Life Sci. 2020, 63, 457-460. [CrossRef]

34. Wan, Y.; Shang, J.; Graham, R.; Baric, R.S.; Li, F. Receptor Recognition by the Novel Coronavirus from Wuhan: An Analysis Based on Decade-Long Structural Studies of SARS Coronavirus. J. Virol. 2020. [CrossRef] [PubMed]

35. Letko, M.; Marzi, A.; Munster, V. Functional assessment of cell entry and receptor usage for SARS-CoV-2 and other lineage B betacoronaviruses. Nat. Microbiol. 2020. [CrossRef] [PubMed]

36. Giovanetti, M.; Benvenuto, D.; Angeletti, S.; Ciccozzi, M. The first two cases of 2019-nCoV in Italy: Where they come from? J. Med. Virol. 2020. [CrossRef] [PubMed]

37. Angeletti, S.; Benvenuto, D.; Bianchi, M.; Giovanetti, M.; Pascarella, S.; Ciccozzi, M. COVID-2019: The role of the nsp2 and nsp3 in its pathogenesis. J. Med. Virol. 2020. [CrossRef]

38. Agostini, M.L.; Andres, E.L.; Sims, A.C.; Graham, R.L.; Sheahan, T.P.; Lu, X.; Smith, E.C.; Case, J.B.; Feng, J.Y.; Jordan, R.; et al. Coronavirus susceptibility to the antiviral remdesivir (GS-5734) is mediated by the viral polymerase and the proofreading exoribonuclease. MBio 2018. [CrossRef]

39. Sheahan, T.P.; Sims, A.C.; Leist, S.R.; Schäfer, A.; Won, J.; Brown, A.J.; Montgomery, S.A.; Hogg, A.; Babusis, D.; Clarke, M.O.; et al. Comparative therapeutic efficacy of remdesivir and combination lopinavir, ritonavir, and interferon beta against MERS-CoV. Nat. Commun. 2020. [CrossRef]

40. Holshue, M.L.; DeBolt, C.; Lindquist, S.; Lofy, K.H.; Wiesman, J.; Bruce, H.; Spitters, C.; Ericson, K.; Wilkerson, S.; Tural, A.; et al. First case of 2019 novel coronavirus in the United States. N. Engl. J. Med. 2020. [CrossRef]

41. Wang, M.; Cao, R.; Zhang, L.; Yang, X.; Liu, J.; Xu, M.; Shi, Z.; Hu, Z.; Zhong, W.; Xiao, G. Remdesivir and chloroquine effectively inhibit the recently emerged novel coronavirus (2019-nCoV) in vitro. Cell Res. 2020, 30, 269-271. [CrossRef]

42. Wang, D.; Hu, B.; Hu, C.; Zhu, F.; Liu, X.; Zhang, J.; Wang, B.; Xiang, H.; Cheng, Z.; Xiong, Y.; et al. Clinical Characteristics of 138 Hospitalized Patients with 2019 Novel Coronavirus-Infected Pneumonia in Wuhan, China. JAMA J. Am. Med. Assoc. 2020. [CrossRef]

43. Li, H.; Wang, Y.M.; Xu, J.Y.; Cao, B. Potential antiviral therapeutics for 2019 Novel Coronavirus. Zhonghua Jie He He Hu Xi Za Zhi 2020. [CrossRef]

44. Savarino, A.; Boelaert, J.R.; Cassone, A.; Majori, G.; Cauda, R. Effects of chloroquine on viral infections: An old drug against today's diseases? Lancet Infect. Dis. 2003, 3, 722-727. [CrossRef] 
45. Vincent, M.J.; Bergeron, E.; Benjannet, S.; Erickson, B.R.; Rollin, P.E.; Ksiazek, T.G.; Seidah, N.G.; Nichol, S.T. Chloroquine is a potent inhibitor of SARS coronavirus infection and spread. Virol. J. 2005. [CrossRef] [PubMed]

46. Casorla-Pérez, L.A.; López, T.; López, S.; Arias, C.F. The Ubiquitin-Proteasome System Is Necessary for Efficient Replication of Human Astrovirus. J. Virol. 2017. [CrossRef] [PubMed]

47. Schneider, M.; Ackermann, K.; Stuart, M.; Wex, C.; Protzer, U.; Schätzl, H.M.; Gilch, S. Severe Acute Respiratory Syndrome Coronavirus Replication Is Severely Impaired by MG132 due to Proteasome-Independent Inhibition of M-Calpain. J. Virol. 2012. [CrossRef]

48. Barretto, N.; Jukneliene, D.; Ratia, K.; Chen, Z.; Mesecar, A.D.; Baker, S.C. The Papain-Like Protease of Severe Acute Respiratory Syndrome Coronavirus Has Deubiquitinating Activity. J. Virol. 2005. [CrossRef]

49. Lindner, H.A.; Fotouhi-Ardakani, N.; Lytvyn, V.; Lachance, P.; Sulea, T.; Menard, R. The Papain-Like Protease from the Severe Acute Respiratory Syndrome Coronavirus Is a Deubiquitinating Enzyme. J. Virol. 2005. [CrossRef]

50. Tibullo, D.; Barbagallo, I.; Giallongo, C.; Vanella, L.; Conticello, C.; Romano, A.; Saccone, S.; Godos, J.; Di Raimondo, F.; Li Volti, G. Heme oxygenase-1 nuclear translocation regulates bortezomibinduced cytotoxicity and mediates genomic instability in myeloma cells. Oncotarget 2016. [CrossRef]

51. Gao, G.; Luo, H. The ubiquitin-proteasome pathway in viral infections. Can. J. Physiol. Pharmacol. 2006, 84, 5-14. [CrossRef]

52. Tibullo, D.; Longo, A.; Vicario, N.; Romano, A.; Barbato, A.; Rosa, M.D.; Barbagallo, I.; Anfuso, C.D.; Lupo, G.; Gulino, R.; et al. Ixazomib improves bone remodeling and counteracts sonic hedgehog signaling inhibition mediated by myeloma cells. Cancers 2020, 12, 323. [CrossRef]

53. Wang, J. Fast Identification of Possible Drug Treatment of Coronavirus Disease -19 (COVID-19) Through Computational Drug Repurposing Study. J. Chem. Inf. Model. 2020. [CrossRef]

54. Moutzouris, J.P.; Che, W.; Ramsay, E.E.; Manetsch, M.; Alkhouri, H.; Bjorkman, A.M.; Schuster, F.; Ge, Q.; Ammit, A.J. Proteasomal inhibition upregulates the endogenous MAPK deactivator MKP-1 in human airway smooth muscle: Mechanism of action and effect on cytokine secretion. Biochim. Biophys. Acta Mol. Cell Res. 2010. [CrossRef] [PubMed]

55. Yu, G.-Y.; Lai, M.M.C. The Ubiquitin-Proteasome System Facilitates the Transfer of Murine Coronavirus from Endosome to Cytoplasm during Virus Entry. J. Virol. 2005. [CrossRef] [PubMed]

56. Inoue, Y.; Tanaka, N.; Tanaka, Y.; Inoue, S.; Morita, K.; Zhuang, M.; Hattori, T.; Sugamura, K. Clathrin-Dependent Entry of Severe Acute Respiratory Syndrome Coronavirus into Target Cells Expressing ACE2 with the Cytoplasmic Tail Deleted. J. Virol. 2007. [CrossRef] [PubMed]

57. Perlman, S.; Netland, J. Coronaviruses post-SARS: Update on replication and pathogenesis. Nat. Rev. Microbiol. 2009, 7, 439-450. [CrossRef]

58. Wang, S.; Guo, F.; Liu, K.; Wang, H.; Rao, S.; Yang, P.; Jiang, C. Endocytosis of the receptor-binding domain of SARS-CoV spike protein together with virus receptor ACE2. Virus Res. 2008. [CrossRef]

59. Yang, Z.-Y.; Huang, Y.; Ganesh, L.; Leung, K.; Kong, W.-P.; Schwartz, O.; Subbarao, K.; Nabel, G.J. $\mathrm{pH}$-Dependent Entry of Severe Acute Respiratory Syndrome Coronavirus Is Mediated by the Spike Glycoprotein and Enhanced by Dendritic Cell Transfer through DC-SIGN. J. Virol. 2004. [CrossRef]

60. Satija, N.; Lal, S.K. The molecular biology of SARS coronavirus. Ann. N. Y. Acad. Sci. 2007, 1102, $26-38$. [CrossRef]

61. Tan, Y.J.; Lim, S.G.; Hong, W. Understanding the accessory viral proteins unique to the severe acute respiratory syndrome (SARS) coronavirus. Antivir. Res. 2006, 72, 78-88. [CrossRef]

62. Thiel, V.; Ivanov, K.A.; Putics, Á.; Hertzig, T.; Schelle, B.; Bayer, S.; Weißbrich, B.; Snijder, E.J.; Rabenau, H.; Doerr, H.W.; et al. Mechanisms and enzymes involved in SARS coronavirus genome expression. J. Gen. Virol. 2003, 84, 2305-2315. [CrossRef]

63. Snijder, E.J.; van der Meer, Y.; Zevenhoven-Dobbe, J.; Onderwater, J.J.M.; van der Meulen, J.; Koerten, H.K.; Mommaas, A.M. Ultrastructure and Origin of Membrane Vesicles Associated with the Severe Acute Respiratory Syndrome Coronavirus Replication Complex. J. Virol. 2006. [CrossRef]

64. Klumperman, J.; Locker, J.K.; Meijer, A.; Horzinek, M.C.; Geuze, H.J.; Rottier, P.J. Coronavirus M proteins accumulate in the Golgi complex beyond the site of virion budding. J. Virol. 1994. [CrossRef] 
65. Stertz, S.; Reichelt, M.; Spiegel, M.; Kuri, T.; Martínez-Sobrido, L.; García-Sastre, A.; Weber, F.; Kochs, G. The intracellular sites of early replication and budding of SARS-coronavirus. Virology 2007. [CrossRef] [PubMed]

66. Raaben, M.; Posthuma, C.C.; Verheije, M.H.; te Lintelo, E.G.; Kikkert, M.; Drijfhout, J.W.; Snijder, E.J.; Rottier, P.J.M.; de Haan, C.A.M. The Ubiquitin-Proteasome System Plays an Important Role during Various Stages of the Coronavirus Infection Cycle. J. Virol. 2010. [CrossRef] [PubMed]

67. Kisselev, A.F.; Goldberg, A.L. Proteasome inhibitors: From research tools to drug candidates. Chem. Biol. 2001, 8, 739-758. [CrossRef]

68. Burger, A.M.; Seth, A.K. The ubiquitin-mediated protein degradation pathway in cancer: Therapeutic implications. Eur. J. Cancer 2004. [CrossRef]

69. Meng, L.; Mohan, R.; Kwok, B.H.B.; Elofsson, M.; Sin, N.; Crews, C.M. Epoxomicin, a potent and selective proteasome inhibitor, exhibits in vivo antiinflammatory activity. Proc. Natl. Acad. Sci. USA 1999. [CrossRef]

70. Ostrowska, H.; Wojcik, C.; Omura, S.; Worowski, K. Lactacystin, a specific inhibitor of the proteasome, inhibits human platelet lysosomal cathepsin A-like enzyme. Biochem. Biophys. Res. Commun. 1997. [CrossRef]

(C) 2020 by the authors. Licensee MDPI, Basel, Switzerland. This article is an open access article distributed under the terms and conditions of the Creative Commons Attribution (CC BY) license (http://creativecommons.org/licenses/by/4.0/). 